\title{
MICROBIAL BIODEGRADATION POTENTIAL OF PETROLEUM-AND NATURE OILS BY INDIGENOUS HYDROCARBON DEGRADING BACTERIA ISOLATED FROM PETRO-CONTAMINATED SITES
}

\author{
Mohammed A. Fahmy ${ }^{*}$, S.H. Salem, H.I. Abd El-Fattah and B.A. Akl \\ Agric. Microbiol. Dept., Fac. Agric., Zagazig Univ., Egypt
}

Received: 01/08/2017; Accepted: 16/08/2017

\begin{abstract}
The study was carried out as an effort at developing active natural petroleum hydrocarbon degraders that could be of relevance of bioremoval of petro-and non-petro oil pollutants from contaminated sites, a collection of 10 bacterial isolates as well as 3 yeast strains and Enterobacter clocace spp. disssolvens strain as efficient petro-hydrocarbon degraders were employed in this study to reach to this target. These bacterial isolates were identified to genus and species level using matrix-assisted laser desorption ionization-time of flight mass spectrometry (MALD-TOF-MS) with high degree of precision (2.111-3.361) as an efficient approach for unambiguous identification process in real sample within minutes. Two experimental techniques, namely respirometric method $\left(\mathrm{CO}_{2}\right.$ production) and the redox indicator 2,6-dichlorophenol indophenol (DCPIP) test were carried out to evaluate the capacity of the tested organisms to utilize monoaromatic hydrocacbons (BTEXmixture) and/or $n$-hexadecane as an excellent substrates in the study of hydrocarbon biodegradation in the tested media, individual and/or mixed bacterial and yeast consortium. The results indicated that the tested organisms showed different rate and extent of growth as well as mixed bacterial-or yeast consortium showed more growth and degradation. Also, some growth condition factors that affect the success of biodegradation were determined, and obtained results revealed that $\mathrm{pH}(7.0)$, temperature $\left(30-35^{\circ} \mathrm{C}\right)$, salinity $(0.0 \%$ and $0.5 \% \mathrm{NaCl})$ and incubation period (11 days) were suitable for the most tested bacteria. The results showed also that only five bacterial strains out of 10 strains namely: Sphingobacterium thalpophilum QBII-6, Pseudomonas nitroreducens RdI-14, Bacillus subtilis ssp subtilis GH-5, B. atrophaeus GH-6 and B. licheniformis RdI-17 as well as Ent. clocace spp. disssolvens exhibited the highest capability to metabolize a diverse range petroleum oils (crude oil, diesel oil, engine oil, used engine oil) and natural oils (corn oil, used corn oil, sunflower oil and used sunflower oil), and these five bacterial types could be applicable in bioremediation process of pollutants after carrying out future studies in field condition as a final goal.
\end{abstract}

Key words: Petroleum hydrocarbon, $\mathrm{CO}_{2}$, DCPIP, natural oils, $n$-hexadecane, BTEX.

\section{INTRODUCTION}

Petroleum hydrocarbons are the most common environmental pollutants and oil spills pose a great hazard to terrestrial and marine ecosystems. Oil pollution may arise either accidently or operationally whenever oil is produced, transported, stored, processed or used at sea or on land. Fortunately, the degradation of these oils in the environment is possible through several techniques: physical (Costes and Druelle,

\footnotetext{
* Corresponding author: Tel. : +201068900164

E-mail address: moh.fahmy@zu.edu.eg
}

1997), chemical (Chu and Kwan, 2003) or biological (Mittal and Singh, 2009). The technology commonly used for the soil remediation includes: mechanical, burying, evaporation, dispersion and washing (Sawadogo et al., 2014). However, these methods are expensive and can lead to incomplete depollution (Sonawdekar, 2012; Das and Chandran, 2011). In view of this situation, bioremediation gives a better solution, owing to, it provides efficacy, safety on the long term use, 
cost and simplicity of administration with promising opportunity for better environment (Bento et al., 2003, Williams et al., 2006; Mandri and Lin, 2007).

Recently, biodegradation of pollutants by microbes has been received significant interest as mankind attempts to reduce contamination and construct a pollution free environment (Das and Chandran, 2011; Dindar et al., 2013; Koshlaf and Ball, 2017). Biodegradation by natural population of microorganisms is the most basic and the most reliable mechanisms by which thousands of pollutants including crude oil and its product (Cappello et al., 2007; Haasanshahian et al., 2012) as well as natural oils and their products (Mahalingam and Sampath, 2014). Biodegradation, is a mineralization of organic chemicals, which ultimately leading to the formation of $\mathrm{CO}_{2}, \mathrm{H}_{2} \mathrm{O}$ and biomass (Benedek et al., 2010; Mrozik and Piotrowska-Seget, 2010).

However, a number of limiting factors have been recognized to affect the biodegradation of petroleum hydrocarbons along with temperature, salinity, oxygen concentration, oil concentration, nutrients and hydrocarbon chemical composition (Leahy and Colwell, 1990; Walworth et al., 2001 ; Das and Chandran, 2011).

In the light of these information, the present study was carried out to utilize already existing indigenous bacteria, which were isolated from petro-contaminated Egyptian sites and primary screened for their abilities to utilize monoaromatic hydrocarbon(benzene, toluene, etthylbenzene, and xylene-BTEX-mixture), as well as reference strains from bacteria and yeasts to degrade petroleum and non-petroleum oils through labscale experiments, as well as the growth conditions for optimizing their abilities to utilize of these organic contaminants were monitored.

\section{MATERIALS AND METHODS}

\section{Microbial Used}

After screening 170 bacterial isolates for their efficiencies to biodegrade different hydrocarbons, the highest 10 active bacterial isolates namely :RdI-13, QBII-6, RDI-14, GH- 5, RdI-8, QRII-7, GH-6, RDI -3, RdI-17 and RdI -1 were selected and used in this study. Also, a bacterial strain namely Enterobacter clocace spp. disssolvens, was kindly provided by Dept. Agric. Micro., Fac. Agric., Zagazig Univ., Egypt and it is known as an efficient in hydrocarbon degradation. In addition three yeast strains, namely Candida parapsilosis Complex 9163, Rhodotorula mucilaginosa Harrison 8802, and Pichia anomala Hansen 10186, were purchased from Mycology Centre at Asiut University, Egypt. They characterized by the centre as active hydrocarbon degraders.

\section{Identification of Bacteria}

One large colony of bacterial isolate (enough to fill about one half of a $10-\mu 1$ inoculating loop) was suspended in $70 \%$ ethanol in a $1.5 \mathrm{ml}$ microcertifuge tube. Protein mass identification of bacteria using a Bruker MALD-TOF. Micro Flex mass spectrometer were performed at Academic Park, Faculty of Medicine, Alexandria, University, Egypt (Sauer and Kliem, 2010; Biswas and Rolain, 2013).

\section{Efficiency of Biodegradation}

Two techniques were used to confirm and evaluate the capability of the tested organisms to biodegrade the tested hydrocarbon used in this study (BTEX blend and/or n-hexadecane at $2.0 \%$, as an excellent substrates in biodegradation studies.

\section{Microbial $\mathrm{CO}_{2}$ Production}

Respirometric biodegradation experiment was conducted in a special unit consists of oneliter wide mouth jar, Pyrex, with special lid as recommended by Isermeyer (1952) and Mariano et al. (2009), using $100 \mathrm{~g} / \mathrm{d}$. wt. soil, sandy loam, treated with $2.0 \mathrm{ml}$ BTEX-blend, $2.0 \mathrm{ml}$ of Tween $80,2.0 \mathrm{ml}$ of the tested organism $\left(10^{7}\right.$ $\mathrm{CFU} / \mathrm{ml}$ ), and the water content was brought to $55 \%$ of water holding capacity (WHC). The prepared soil jars were incubated at $28^{\circ} \mathrm{C}$ and the titration process was carried out after $0,3,7$, 14 and 28 days of incubation. The output of $\mathrm{CO}_{2}$ was trapped in $100 \mathrm{ml} \mathrm{KOH}$ and measured by titrating the residual $\mathrm{KOH}$ with standard solution of $\mathrm{HCl}(0.1 \mathrm{~N}),(1 \mathrm{ml}$ of $0.1 \mathrm{~N} \mathrm{HCl}$ equivalent $2.20 \mathrm{mg} \mathrm{CO}_{2}$ ), and the obtained results were expressed as $\mathrm{mg} \mathrm{CO}_{2} / 100 \mathrm{~g}$. d. wt. soil. 


\section{DCPIP Redox Indicator Technique}

2,6-dichlorophenol indophenol indicator was used to confirm the ability of the tested organisms to utilize BTEX blend and/or nhexadecane as carbon source in Bushnell Haas mineral medium in the test tubes as recommended by Hanson et al. (1993) and Mariano et al. (2009). In this technique, time taken for decolourization of the blue (oxidized) DCPIP to colorless (reduced) form was recorded for each isolate per hour.

\section{Optimizing the Growth Conditions}

Optimizing the bacterial growth conditions (temperature, $\mathrm{pH}$, salinity, and incubation periods) for the 10 selected active strains, were determined using trypticase soy broth medium supplemented with $n$-hexadecane $(2.0 \%)$ as a carbon source as follows:

\section{Effect of Temperature on Bacterial Growth}

The influence of temperature $(25,30,35$ and $40^{\circ} \mathrm{C}$ ) on the growth of the tested bacteria in 250 $\mathrm{ml}$ Erlenmeyer flasks containing $100 \mathrm{ml}$ of trypticase soy broth supplemented with $2.0 \mathrm{ml}$ n-hexadecane (after sterilization). The flasks were inoculated with $1 \mathrm{ml}$ of overnight cultures at the log phase of growth was studied. The experiment was conducted at $\mathrm{pH} 7$ and incubated for 11 days for all levels of temperature using rotary shaker at $150 \mathrm{rpm}$. The growth was monitored through culture densities measuring light absorption spectrophotometrically (Jenway 6405 UV-VIS spectrophotometer, UK) at $600 \mathrm{~nm}$. (Mahalingam and Sampath, 2014).

\section{Effect of pH on Bacterial Growth}

The effect of the initial $\mathrm{pH}$ values of 6.5, 7.0, 7.5 and 8.0 on the growth of the 10 bacterial strains were estimated by growing them as mentioned above, and incubated at $30^{\circ} \mathrm{C} \pm 0.5^{\circ} \mathrm{C}$ for 11 days using rotary shaker at $150 \mathrm{rpm}$. The bacterial growth of the tested cultures was determined spectrophotometrically at $600 \mathrm{~nm}$. (Mahalingam and Sampath, 2014).

\section{Effect of Salinity on Bacterial Growth}

The influence of sodium chloride at different concentrations in trypticase soy broth media $(0$, $0.5,2.5$ and $5.0 \%$ ) supplemented with hydrocarbon $\mathrm{n}$-hexadecane on the growth of the tested bacteria was measured for all concentrations. The experiment was conducted at $\mathrm{pH} 7.0$ and $30^{\circ} \mathrm{C}$ for 11 days of incubation using rotary shaker at $150 \mathrm{rpm}$. The growth was monitored through culture densities measuring light absorption spectrophotometrically at $600 \mathrm{~nm}$. (Margesin and Schinner, 2001; Qin et al., 2012).

\section{Effect of the Incubation Periods on Bacterial Growth}

In this experiment, the effect of incubation periods at 3, 7, 11 and 15 days on the growth of the tested strains was studied using tripticase soy broth media $(100 \mathrm{ml})$ supplemented with $2.0 \mathrm{ml}$ of $n$-hexadecane at $\mathrm{pH} 7.0$, temperature $30^{\circ} \mathrm{C}$ and $\mathrm{NaCl} 0.0 \%$ using rotary shaker at $150 \mathrm{rpm}$. The growth of the tested cultures (at $600 \mathrm{~nm}$ ) was determined in the desired time interval to record the best incubation period for these strains (Mishra and Singh, 2012).

\section{Evaluation the Growth and Ability of the Tested Bacteria for Using Different Hydrocarbon and Organic Compounds}

In this experiment, the 10 hydrocarbon degraders bacteria, were tested to study their ability to grow on some other petroleum hydrocarbons (diesel oil - used engine oil-engine oil and crude oil) as well as some organic compounds (corn oil, used corn oil, sunflower oil and used sunflower oil) as a carbon and energy sources (Malatova, 2005). This experiment was conducted in duplicates using BushnellHaas broth medium in $250 \mathrm{ml}$ Erlenmeyer flasks containing $100 \mathrm{ml}$ supplemented with $2.0 \mathrm{ml}$ of the tested compounds. The experimental conditions were: $\mathrm{pH} 7.0$, incubation temperature $30^{\circ} \mathrm{C}$, salinity $\mathrm{NaCl} 0.5 \mathrm{~g}$ and incubation period 11 days and shaking at $150 \mathrm{rpm}$. The bacterial growth (at $600 \mathrm{~nm}$ ) of the cultures was estimated at the final phase of the experiment.

\section{Statistical Analyses}

Each treatment was run in three replicates and the data were statistically analyzed by CoStat version 6.311 Copyright(c) 1998-2005 CoHort Softwar, http://www.cohort.com.

\section{RESULTS AND DISCUSSION}

\section{Direct Identification of the Tested Bacteria Using MALDI-TOF-MS}

The 10 active hydrocarbon bacterial isolates codes: RdI-13, QBII-6, RDI-14, GH- 5, RdI-8, QRII-7, GH-6, RDI-3, RdI-17 and RdI-1 were 
identified at Academic Park Fac. Medicine Alex. Univ., Egypt, using MALDI-TOF- MS. (matrix-assisted layser desorption inonizationtime of flight mass spectrometry). This strategy generates a spectrum based on protein detected directly from intact microorganisms, allowing a rapid identification, and it took the leading position in just a few years. This success in based on MALD's short analysis, high sensitivity and intact cell measurement, as well as the possibility of automation, therefore it has become the method of choice throughout the third millennium, (Krasny et al., 2013). This strategy was the good argument to have accurate and direct identification of the tested bacteria. In this advanced method, the identification process was confirmed and the prospective strains with their numbers as conserved in the International Cultural Centers for Microorganisms were registered. The obtained results of score value for each bacterial isolates are shown in Table 1 .

Of the 10 isolates with a score value between 2.111 to $2.361(100 \%)$ organisms were correctly identified by MALDI- TOF- MS to genus and species levels. All the tested bacterial strains were type strains that are included in the Bruker Database, and all spectrum scores were greater than 2.0. Thus, all of the tested bacterial hydrocarbon degraders were correctly identified to genus and species levels by the Micro Flex LT mass spectrophotometer with biotype software score values greater than 2.0, and all of them had high degree of precision. On the other hand, two isolates only were identified to genus, species and subspecies levels as recorded in isolate No. 2 and isolate No. 6 (Table 1). Thus, they were completely identified as they were as follows Bacillus subtilis ssp.subtilis DSM $10 \mathrm{~T}$ DSM and B. subtilis ssp. spizizenii DSM 618 DSM and their similarity scores were 2.332 $\{\mathrm{C} 1(+++)(\mathrm{A})\}$ and $2.323 \quad \mathrm{C} 6(+++)(\mathrm{A})\}$, respectively. In this respect, Bille et al. (2012) pointed out that this method allowed a proper identification of bacteria grown on solid media to reach $99.20 \%$ cases (2609 out of 2630 organisms) Also, it is well known that in most cases, the 16S rRNA sequencing results agreed with MALDI- TOF- MS identification (Bizzini et al., 2010 ; Wang et al., 2013) presumably owing to co-evolution of ribosomal proteins and ribosomal nucleic acids (Sauer and Kliem, 2010).

\section{Microbial Biodegradation Potential of Petroleum Hydrocarbon}

\section{The time required to decolourize redox indicator DCPIP}

By incorporating an electron acceptor such as DCPIP to the culture medium, it is possible to ascertain the ability of organism to utilize the substrate by observing the colour change of DCPIP from Blue (oxidized) to colorless (reduced), (Hanson et al., 1993 ; Mariano et al., 2009), and the obtained results are giving in Table 2.

Results presented in this Table show that there were great variations in the time (in hours) to decolourize the DCPIP indicator by the tested bacteria as well as yeast strains and consortium from yeasts or bacterial strains. This time was ranged from 22 to $49 \mathrm{hr}$., in the case of n-hexadecane and 39 to $86 \mathrm{hr}$., in the case of BTEX-blend.

As for n-hexadecane, as an example of alkanes group, two strains, namely Bacillus licheniformis RdI-17 and Pseudomonas nitroreducens RdI-14 caused a discolourization of DCPIP indicators after 29 and $30 \mathrm{hr}$, respectively. These strains showed a maximum utilization of the tested hydrocarbon $n$ hexadecane in shortest time and can be considered as the best alkanes biodegraders among the tested bacteria. On the other hand, the longest time was recorded in the case of strain Bacillus mojavensis QRII 7 and Bacillus pumilus RdI-1 being just in $40 \mathrm{hr}$., and $49 \mathrm{hr}$., respectively.

Regarding the BTEX blend, as an example of monoaromatic hydrocarbon compounds used in this experiment, only two active strains, Bacillus licheniformis RdI-17 and Pseudomonas nitroreducens RdI-14 which were recorded in the case of n-hexadecane, and showed also the shortest time in the case of BTEX-blend being 51 and $52 \mathrm{hr}$., respectively, among the tested bacteria for the decolourization of the blue BCPIP to the colorless form. These results are in harmony with those obtained by Pirôllo et al. (2008) who mentioned that the Pesudomonas aeruginosa LBI strain caused a discolourization the DCPIP redox indicator in the presence of diesel oil and crude oil after $23 \mathrm{hr}$., in the presence 
Table 1. Classification results rate by Bruker Daltonik MALDI Biotyper

\begin{tabular}{|c|c|c|c|c|}
\hline $\begin{array}{l}\text { Isolate } \\
\text { number }\end{array}$ & $\begin{array}{c}\text { Isolate } \\
\text { code }\end{array}$ & Analyte name & Organism (best match) & $\begin{array}{l}\text { Score } \\
\text { value }\end{array}$ \\
\hline 1 & RdI-13 & $\underline{\mathrm{C} 5}(++)(\mathrm{B})$ & Bacillus licheniformis $992000432 \mathrm{LBK}$ & $\underline{2.111}$ \\
\hline 2 & GH-5 & $\underline{\mathrm{C} 1}(+++)(\mathrm{A})$ & Bacillus subtilis ssp. subtilis DSM $10 T$ DSM & $\underline{2.332}$ \\
\hline 3 & GH-6 & $\underline{\mathrm{C} 2}(++)(\mathrm{B})$ & Bacillus atrophaeus DSM 5551 DSM & $\underline{2.121}$ \\
\hline 4 & RdI-14 & $\underline{\mathrm{C} 3}(++)(\mathrm{B})$ & Pseudomonas nitroreducens LMG 20221 T HAM & $\underline{2.129}$ \\
\hline 5 & RdI-8 & $\underline{\mathrm{C}} 4(++)(\mathrm{B})$ & Bacillus subtilis 107_W_7_QSA IBS & $\underline{2.120}$ \\
\hline 6 & RdI-3 & $\underline{\mathrm{C} 6}(+++)(\mathrm{A})$ & Bacillus subtilis ssp. spizizenii DSM 618 DSM & $\underline{2.323}$ \\
\hline 7 & RdI-17 & $\underline{\mathrm{C}}(+++)(\mathrm{A})$ & Bacillus licheniformis CS 54_l BRB & $\underline{2.361}$ \\
\hline 8 & QRII-7 & $\underline{\mathrm{C} 8}(++)(\mathrm{B})$ & Bacillus mojavensis DSM 9205T DSM & $\underline{2.130}$ \\
\hline 9 & QBII-6 & $\underline{\mathrm{C} 9}(++)(\mathrm{B})$ & Sphingobacterium thalpophilum DSM 11723 T HAM & $\underline{2.119}$ \\
\hline 10 & RdI-1 & $\mathrm{C} 10(++)(\mathrm{B})$ & Bacillus pumilus DSM 1794 DSM & $\underline{2.151}$ \\
\hline
\end{tabular}

- Category A= species consistency (2.300-3.000), Category B = genus consistency (2.000-2.299)

Table 2. Changes in the time (in hours) for decolorization of DCPIP indicator at $0.1 \%$ in Bushnell-Haas broth by the tested bacterial and yeast strains, alone and with a consortium

\begin{tabular}{|c|c|c|c|}
\hline \multicolumn{2}{|c|}{$\overline{\text { Organism }}$} & \multicolumn{2}{|c|}{$\begin{array}{c}\text { Time of decolorization of DCPIP during the } \\
\text { experiment }(96 \mathrm{hr} \text {.) }\end{array}$} \\
\hline & & $n$-hexadecane & BTEX-blend \\
\hline \multirow{10}{*}{ 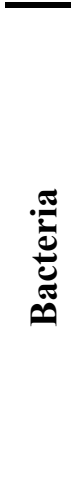 } & Control & No decolorization & No decolorization \\
\hline & Bacillus licheniformis RdI-13 & $37 \mathrm{~g}$ & $65 \mathrm{~h}$ \\
\hline & Sphingobacterium thalpophilum QBII-6 & $33 \mathrm{e}$ & $56 \mathrm{f}$ \\
\hline & Pseudomonas nitroreducens RdI-14 & $30 \mathrm{c}$ & $52 \mathrm{~d}$ \\
\hline & Bacillus subtilis ssp subtilis GH-5 & $31 \mathrm{~d}$ & $54 \mathrm{e}$ \\
\hline & Bacillus subtilis RdI- 8 & $37 \mathrm{~g}$ & $75 \mathrm{i}$ \\
\hline & Bacillus mojavensis QRII -7 & $40 \mathrm{~h}$ & $77 \mathrm{j}$ \\
\hline & Bacillus atrophaeus GH- 6 & $31 \mathrm{~d}$ & $55 \mathrm{~d}$ \\
\hline & Bacillus subtilis ssp spizizenii RDI- 3 & 33 e & $64 \mathrm{~g}$ \\
\hline & Bacillus licheniformis RdI-17 & $29 \mathrm{~b}$ & $51 \mathrm{c}$ \\
\hline \multirow{4}{*}{\begin{tabular}{l}
$\tilde{a}$ \\
\multirow{E}{*}{} \\
$\dot{\nu}$
\end{tabular}} & Bacillus pumilus RdI-1 & $49 \mathrm{~h}$ & $82 \mathrm{k}$ \\
\hline & Candida parapsilosis Complex 9163 & $41 \mathrm{i}$ & $82 \mathrm{k}$ \\
\hline & Rhodotorula mucilaginosa Harrison 8802 & $42 \mathrm{j}$ & 851 \\
\hline & Pichia anomala Hansen10186 & $41 \mathrm{i}$ & $86 \mathrm{~m}$ \\
\hline \multirow{3}{*}{ 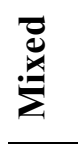 } & Mixed 10 bacteria strains & $22 \mathrm{a}$ & $39 \mathrm{a}$ \\
\hline & Mixed 3 yeasts strains & $34 \mathrm{f}$ & $50 \mathrm{~b}$ \\
\hline & LSD 0.05 & 0.0962 & 0.0962 \\
\hline
\end{tabular}


of kerosene after $68 \mathrm{hr}$, and partial discolourization in oil sludge after $72 \mathrm{hr}$. Smilar results were also reported by Bidoia et al. (2010) who found that the tested cultures of bacteria can completely reduce DCPIP in 75, 87, 125 and $138 \mathrm{hr}$., for mineral oil, used oil, semisynthetic and synthetic oil, respectively.

As seen for yeast strains, results in Table 2 reveal that they showed shortest time to decolorize of the DCPIP indicator within 41-42 hr., in the case of $n$-hexadecane and within 82 $86 \mathrm{hr}$., of incubation in the case of BTEX- blend was shown. It seems that the tested yeast strains had the lower ability than the tested bacterial strains to biodegrade the tested hydrocarbon compounds under this study. In general, it is well known that fungi withstand harsher environmental conditions than bacteria and could play an important role in the degradation of petroleum hydrocarbons in the soil (Bossert and Bartha, 1984). Also, the obtained results in Table 2 clearly reveal that the mixed 10 bacterial strains (as consortium no.1) showed maximum $n$-hexadecane and BTEX-blend biodegradation as indicated by the shortest time of DCPIP discolouration being 22 and $39 \mathrm{hr}$., respectively as compared to the tested individual bacteria. The same trend was also recorded in the case of the addition of yeast strains, as consortium No. 2, it enhanced the total discolouration of DCPIP in the presence of n-hexadecane and BTEX-blend after 34 and 50 hr., respectively as compared to single yeast strains tested. In general, these results are in agreement with those reported by Rahman et al. (2002) who stated that individual bacterial cultures, Micrococcus sp. GS2-22, Corynebacterium sp. GS5-66, Flavobacterium sp. DS5-73, Bacillus sp. DS 6-86 and Pseudomonas sp. DS 10-129, showed less growth and degradation of Bombay high crude oil than did the mixed bacterial consortium prepared using the above strains.

\section{Changes in the Amounts of $\mathrm{CO}_{2}$ Evolution}

Mineralization studies involving measurement of total $\mathrm{CO}_{2}$ production can provide excellent information on the biodegradability potential of hydrocarbon (Balba et al., 1998). This process rely on the natural ability of microorganisms to carry out the mineralization of organic chemicals leading ultimately to the formation of $\mathrm{CO}_{2}, \mathrm{H}_{2} \mathrm{O}$ and biomass. Monitoring of $\mathrm{CO}_{2}$ produced during 28-day assays by the tested microorganisms is shown in Figs. 1, 2 and 3.

Data in Figs. 1 and 2 revealed that the evolution of $\mathrm{CO}_{2}$, in the case of the tested bacteria, reached its peak after 3 days of incubation, as indicated by the rate of $\mathrm{CO}_{2}$ output during the time course of the experiment, in the case of Pseudomonas nitroreducens RdI-14, B. subtilis RdI-8 and B. mojavensis QRII-7 and after 7 days in the remainder bacterial strains. Also, the same trend was recorded in the case of yeast strains used, since the peak was reached after 3 days in the case of Candida parapsilosis Complex 9163 and Pichia anomala Hansen 10186, and 7 days in the case of Rhodotorula mucilaginosa Harrison 8802. The same trends of daily $\mathrm{CO}_{2}$ production during incubation period were also reported by Mariano et al. (2007), who found that respirometric data indicated that a maximum hydrocarbon mineralization of $19 \%$, obtained through the combination of the three agents, addition of nitrogen and phosphorus solutions or Tween 80 surfactant, with a total petroleum hydrocarbon removal of $45.5 \%$ in 55 days of treatment.

Also, it is obvious from Data in Figs. 1 and 2 that as the time of the experiment proceeded thereafter, the amount of $\mathrm{CO}_{2}$ evolved were gradually decreased up to the end of the experiment in both bacteria and yeast strains. This decline in $\mathrm{CO}_{2}$ production might be attributed to the decline in density of microbial population, which was deduced to the exhaustion of the available degradable organic fraction. In this connection, Sabate et al. (2004) mentioned that, this decline could be attributed to the absence of assimilable sources of carbon and energy or to the presence of toxic compounds in soil.

The rate and extent of biodegradtion might be attributed to the strain ability as well as the number of aromatic ring present and the nature of the linkage between these rings in the tested monoaromatic hydrocarbon, BTEX-mixture. However, Mariano et al. (2007) mentioned that, this variation may be caused by a transition of carbon sources. As the labile hydrocarbon 


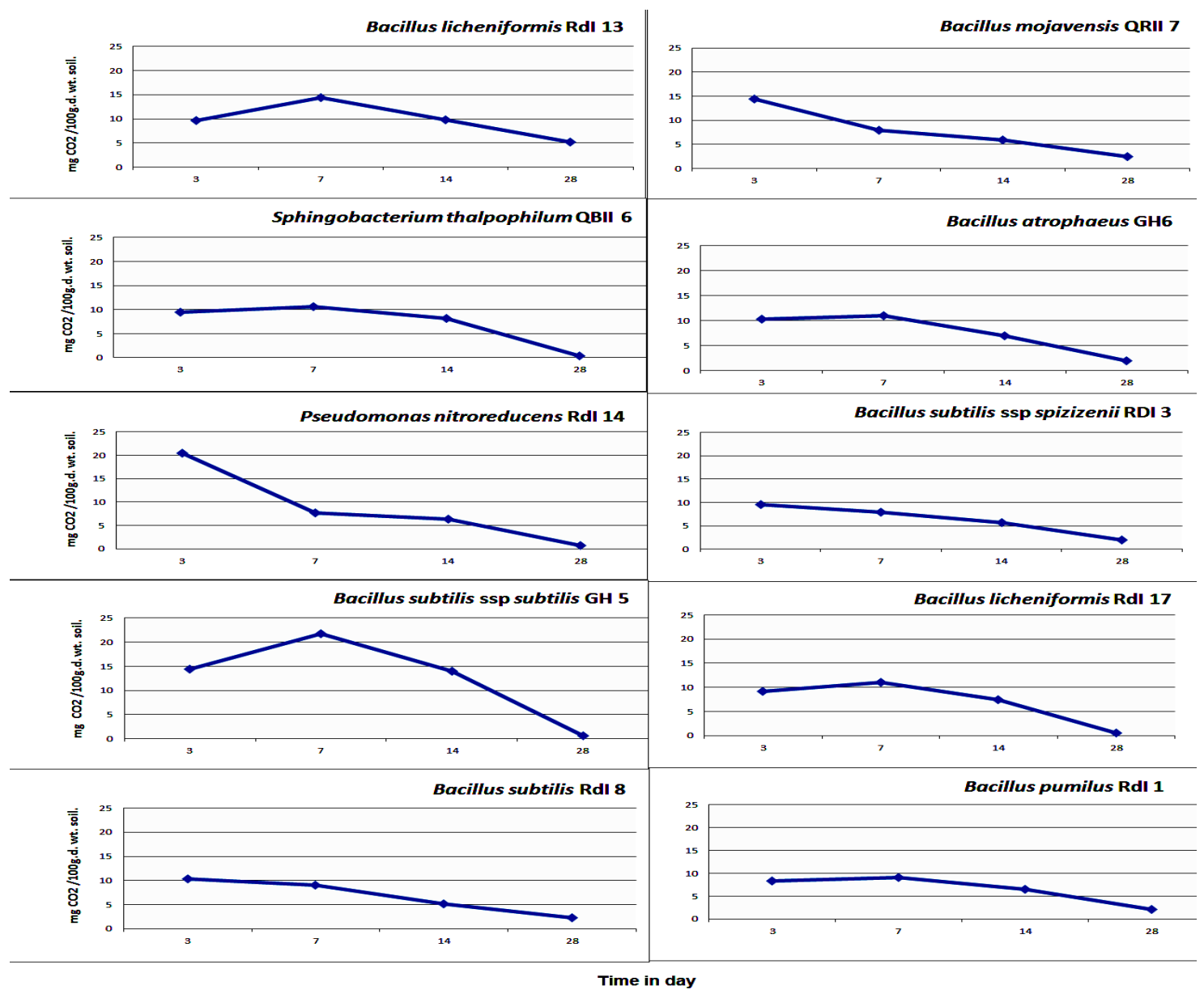

Fig. 1. Changes in the amounts of $\mathrm{CO}_{2}$ from sandy loam soil output during the biodegradation of BTEX blend at $2 \%$ by the best bacterial strains during incubation at $28^{\circ} \mathrm{C}$ for 28 days
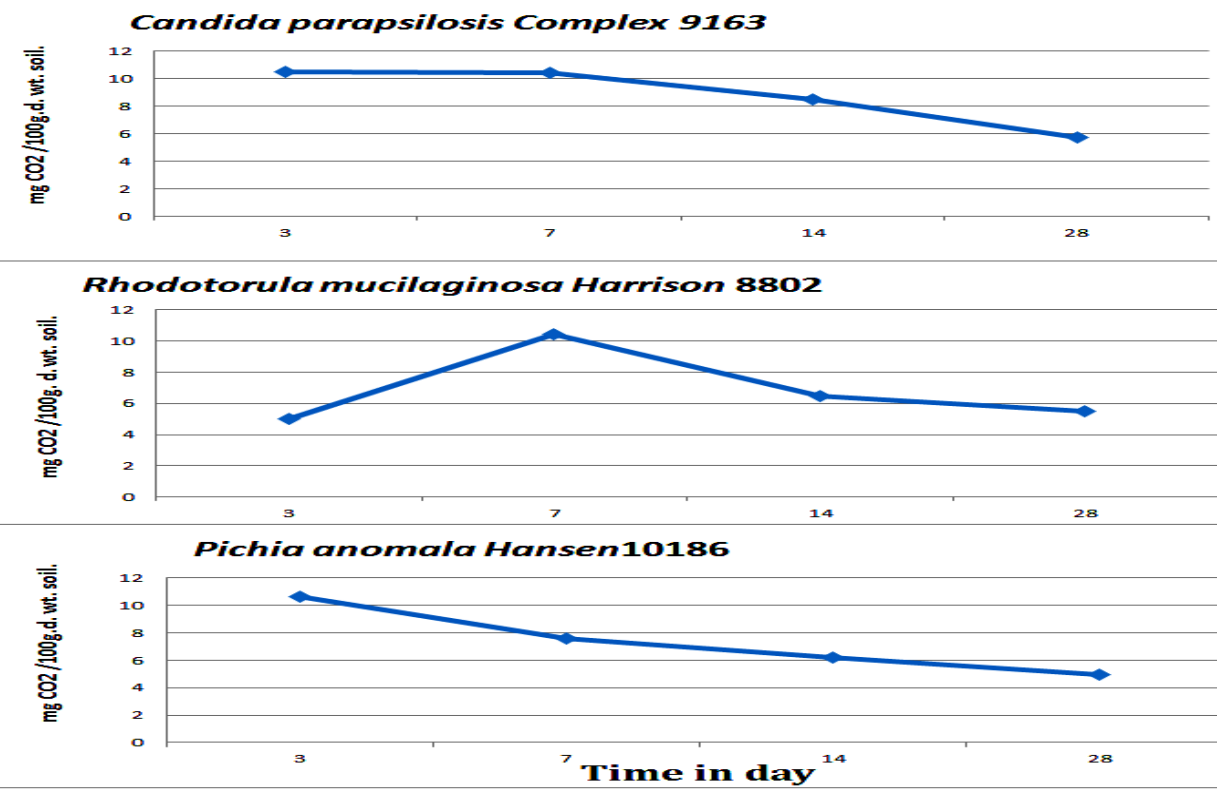

Fig. 2.Changes in the amouts of $\mathrm{CO}_{2}$ output from sandy loam soil during the biodegradation of BTEX blend at $2 \%$ by three standard yeasts strains during incubation at $28^{\circ} \mathrm{C}$ for 28 days 


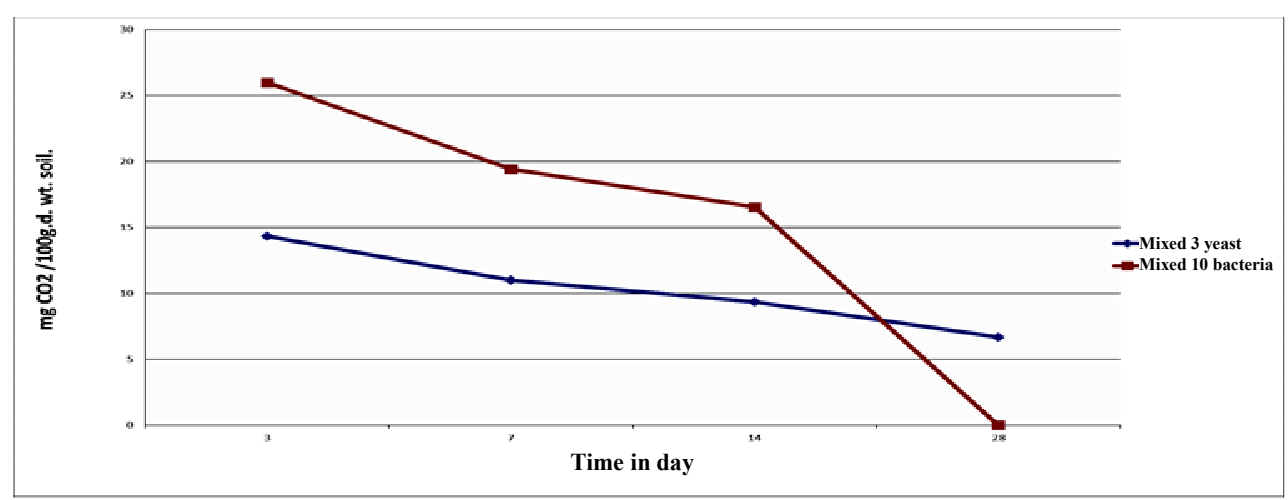

Fig. 3. Changes in the amouts of $\mathrm{CO}_{2}$ output from sandy loam soil during the biodegradation of BTEX blend at $2 \%$ by either mixed bacterial strains or mixed yeasts strains during incubation at $28^{\circ} \mathrm{C}$ for 28 days

sources (probably linear and open-chain hydrocarbons) are consumed, their bioavilability decreases. The shortage of these sources forces the microorganisms to adapt to more recalcitrant sources (probably aromatic hydrocarbon with higher molecular weight), resulting in decrease of the $\mathrm{CO}_{2}$ production.

When each of the active hydrocarbon bacterial or yeast degraders were mixed then added to the soil as consortium (No.1 and No.2), considerable amounts of $\mathrm{CO}_{2}$ uptake were recorded during the time course of the experiment. Also, the rate of $\mathrm{CO}_{2}$ production reached its peak after 3 days of incubation, being 25,978 and $14.345 \mathrm{mg} \quad \mathrm{CO}_{2} /$ day/100 g.d.wt. soil, as well as the average daily rate of $\mathrm{CO}_{2}$ production were 2.477 and $1.502 \mathrm{mg} \mathrm{CO} /$ day in the case of consortium No. 1 and consortium No. 2, respectively. The mixed bacterial strains and yeast strains as a specific consortium showed more growth and degradation of BTEX-blend used in this study as indicated by the values of $\mathrm{CO}_{2}$ production and the average daily rate of $\mathrm{CO}_{2}$ production. Also, it is interesting to notice from Figs. 1, 2 and 3 that the amount of $\mathrm{CO}_{2}$ evolved at 28 days, in the case of consortium No.1, reached to zero value. This means that the used 10 bacterial strains, in association form, exhausted or mineralized completely the available degradable hydrocarbon, BTEX-components. Thus, using this bacterial consortium as inoculum provides certain advantages over biostimulation of indigenous microorganisms cases where there is pollutant toxicity or lack of appropriate microorganisms (quantity or quality). In this respect, Leahy and Colwell (1990) reported that mixed population with overall broad enzymatic capacities are required to degrade complex mixture of hydrocarbons such as crude oil and diesel fuel. Such mixed cultures display metabolic superiority to pure cultures (Van Hamme et al., 2000).

In general, microbial consortium can degrade hydrocarbon from oil-contaminated sites more efficiently than pure isolated microorganisms mainly due to synergetic effects. Recently, ElNaas et al. (2014) explained this enhancement to either the presence of different microbial species with a number of metabolic pathways or to interspecies interactions. Therefore, mixed cultures may be more effective than single cultures in biotreatment systems for the complete biodegradation of multicomponent hydrocarbons.

\section{Factors Affecting Biodegradation of Petroleum Hydrocarbons}

\section{Effect of temperature}

It is well known that temperature affects rate of hydrocarbon degradation and the physicochemical compositions of oil, results in enhanced hydrocarbon bioaviability as well as the composition and metabolic activity of the microbial communities (Okoh, 2006; Perfumo et al., 2007; Koshlaf and Ball, 2017). The changes in the bacterial growth of the tested 10 bacterial strains in trypticase soy broth supplemented with $n$-hexadecane at $2.0 \%$ as affected by 
different incubation temperatures are given in Table 3. It is obvious from the results that the tested bacterial strains were able to grow at different temperature degrees viz, 25, 30, 35 and $40^{\circ} \mathrm{C}$. Moreover, there were, in general, from two to three- fold increase in the bacterial growth (O.D $600 \mathrm{~nm}$ ) when the incubation temperature raised from 25 to $30^{\circ} \mathrm{C}$. Also, the results revealed that the highest bacterial biomass of the tested bacterial strains were observed at $35^{\circ} \mathrm{C}$ and showed a positive correlation between the temperature degrees and the bacterial biomass production except in the case of Pseudomonas nitroreducens RDI-14, which showed its maximal growth at $30^{\circ} \mathrm{C}$. At $40^{\circ} \mathrm{C}$, there were noticeable declines in the bacterial growth of all tested bacterial strains. These results confirmed those obtained by Sathishkumar et al. (2008), who reported that temperature of $35^{\circ} \mathrm{C}$ was found to be an optimum for maximum biodegradation of crude oil by individual bacterial strains and a mixed bacterial consortium (Bacillus sp.IO1.7, Corynebacterium sp. Bp2-6, Pseudomonas sp. HPS2.5, and Pseudomonas sp. BPS1.8). Also, Rahman et al. (2002) reported that temperature of $30{ }^{\circ} \mathrm{C}$ was found to be optima for maximum biodegradation of crude oil (from 1 to $10 \%$ ) by Microcoocus sp. GS2.22, Corynebacterium sp. GS5-66, Flavobacterium sp. DS5-73, and Pseudomonas sp. DS10.129 isolates.

In fact, temperature is responsible or controlling the nature and extent of microbial metabolism in hydrocarbons as well as diffusion rates, biovailability and solubility (El-Naas et al., 2014).

\section{Effect of pH}

The bacterial growth in the synthetic media are sensitive to the alternative of $\mathrm{pH}$. Thus, it was necessary to determine the optimum $\mathrm{pH}$ value suitable for petroleum degradation by the selected bacteria. Results in Table 4 show that there were a progressive increase in the bacterial growth $($ O.D $600 \mathrm{~nm})$ for all the tested strains when $\mathrm{pH}$ value of the tested media increased from 6.5 to 7.0. This alteration in $\mathrm{pH}$ value caused considerable bacterial growth rates being seven- and nine-fold increase in the case of Bacillus subtilis RdI-8 and B. pumilus RdI-1, respectively, while the rest of the bacterial strains showed two to four -fold increase in the growth rate.

Results also revealed that only 6 out of 10 bacterial strains, namely Sphingobacterium thalpophilum QBII-6, Bacillus subtilis ssp subtilis GH-5, B. mojavensis QRII-7, B. atrophaeus GH-6, B. licheniformis RdI-17 and Bacillus pumilus RdI-1, showed the highest bacterial growth rates at $\mathrm{pH} 7.0$, while the rest of bacterial strains showed the highest bacterial growth rates at $\mathrm{pH}$ 7.5. Such variation could be attributed to bacterial type per se, microbial behaviour and interaction to utilize $n$-hexadecane as carbon and energy source.

At $\mathrm{pH} 8.0$, there were obvious reduction in the bacterial growth rates for all tested bacterial strains used in this study. Similar results were also obtained by Salmon et al. (1998) and Rahman et al. (1999). Meredith et al. (2000) found that a neutral $\mathrm{pH}$ of 7.0 has been reported to be optimal for petroleum biodegradation and extremes in $\mathrm{pH}$ were shown to have a negative influence on the ability of microbial populations to degrade hydrocarbons. Also, the optimal growth of many tested other diesel degrading bacteria were reported at neutral or near $\mathrm{pH}$, (Ueno et al., 2007 ; Kwapisz et al., 2008). However, El-Naas et al. (2014) stated that most bacteria are neutrophils, so the optimum $\mathrm{pH}$ at which the highest degree of BTEX biodegradation is achieved at $\mathrm{pH} 7.5$, and bacteria and actinomycetes was optimal in a range typically between 7 and 8 .

\section{Effect of salinity}

In this experiment, the ability of the selected 10 active bacterial strains to grow at different $\mathrm{NaCl}$ concentrations viz, $0,0.5,2.5$ and $5.0 \%$ were determined at $30^{\circ} \mathrm{C}, \mathrm{pH} 7.0$ and incubation for 11 days.

The obtained results in this respect are shown in Table 5. It was found that all bacterial strains were very sensitive to $\mathrm{NaCl}$ concentrations used in this study, as indicated by the obvious declines in the bacterial growth rates. On the other hand, these tested bacterial strains were mainly isolated from soil contaminated with hydrocarbons or petroleum sludge samples not from marine environments. 
Table 3. Bacterial growth (O.D $600 \mathrm{~nm})$ of the tested 10 bacterial strains in trypticase soy broth supplemented with $n$-hexadecane at $2.0 \%$ as affected by different incubation temperatures

\begin{tabular}{lcccc}
\hline \multirow{2}{*}{\multicolumn{1}{c}{ Temperature degree }} & \multicolumn{4}{c}{ Bacterial growth (O.D 600 $\mathbf{~ m})$} \\
\cline { 2 - 5 } Bacterial strain & $\mathbf{2 5}{ }^{\circ} \mathbf{C}$ & $\mathbf{3 0}{ }^{\circ} \mathbf{C}$ & $\mathbf{3 5}{ }^{\circ} \mathbf{C}$ & $\mathbf{4 0}{ }^{\circ} \mathbf{C}$ \\
\hline Bacillus licheniformis Rd-I13 & 0.331 & 1.111 & 1.328 & 0.500 \\
Sphingobacterium thalpophilum QBII- 6 & 0.561 & 1.342 & 1.480 & 0.806 \\
Pseudomonas nitroreducens RDI- 14 & 0.500 & 1.471 & 1.330 & 0.880 \\
Bacillus subtilis ssp. subtilis GH -5 & 0.610 & 1.169 & 1.401 & 0.776 \\
Bacillus subtilis RdI- 8 & 0.444 & 1.111 & 1.216 & 0.593 \\
Bacillus mojavensis QRII -7 & 0.500 & 1.091 & 1.309 & 0.716 \\
Bacillus atrophaeus GH -6 & 0.499 & 1.126 & 1.421 & 0.730 \\
Bacillus subtilis ssp. spizizenii RDI- 3 & 0.385 & 1.041 & 1.221 & 0.513 \\
Bacillus licheniformis RdI- 17 & 0.600 & 1.141 & 1.340 & 0.832 \\
Bacillus pumilus RdI-1 & 0.501 & 1.000 & 1.136 & 0.725 \\
LSD 0.05 & 0.0012 & 0.0033 & 0.0011 & 0.0033 \\
\hline
\end{tabular}

Table 4. Bacterial growth (O.D $600 \mathrm{~nm})$ of the tested 10 bacterial strains in trypticase soy broth supplemented with $n$-hexadecane at $\mathbf{2 . 0 \%}$ as affected by different starting $\mathrm{pH}$ levels

\begin{tabular}{lcccc}
\hline \multirow{2}{*}{\multicolumn{1}{c}{ pH value }} & \multicolumn{4}{c}{ Bacterial growth (O.D 600nm) } \\
\cline { 2 - 5 } Bacterial strain & $\mathbf{6 . 5}$ & $\mathbf{7 . 0}$ & $\mathbf{7 . 5}$ & $\mathbf{8 . 0}$ \\
\hline Bacillus licheniformis RdI- 13 & 0.277 & 1.032 & 1.121 & 0.482 \\
Sphingobacterium thalpophilum QBII -6 & 0.482 & 1.391 & 1.321 & 0.832 \\
Pseudomonas nitroreducens RdI -14 & 0.464 & 1.361 & 1.421 & 0.944 \\
Bacillus subtilis ssp. subtilis GH -5 & 0.365 & 1.436 & 1.312 & 0.998 \\
Bacillus subtilis RdI -8 & 0.164 & 1.323 & 0.885 & 0.711 \\
Bacillus mojavensis QRII -7 & 0.053 & 1.190 & 1.130 & 0.666 \\
Bacillus atrophaeus GH -6 & 0.316 & 1.451 & 1.174 & 0.831 \\
Bacillus subtilis ssp. spizizenii RdI -3 & 0.464 & 1.131 & 1.160 & 0.83 \\
Bacillus licheniformis RdI -17 & 0.492 & 1.490 & 1.441 & 0.885 \\
Bacillus pumilus RdI -1 & 0.125 & 1.195 & 1.130 & 0.500 \\
LSD 0.05 & 0.0011 & 0.0670 & 0.0033 & 0.0033 \\
\hline
\end{tabular}


Results in Table 5 show also that, the control treatment was the most suitable for most tested bacterial strains, with some exceptions in the case of Bacillus subtilis RdI-8 and $B$. licheniformis RdI-17, which showed the highest bacterial biomass formation at $0.5 \% \mathrm{NaCl}$.

The obtained results are in line with those reported by Minani-Tehrani et al. (2006) who studied the effect of different $\mathrm{NaCl}$ concentrations $(0.0 \%-5.0 \%)$ on polycyclic aromatic hydrocarbons (PAHs) reduction from the heavy crude oil contaminated soil. They pointed out that the biodegradation of total crude oil was higher at $0.0 \% \mathrm{NaCl}(41 \%)$, while a higher total PAHs reduction was observed at $1.0 \% \mathrm{NaCl}(35 \%)$. The lower reduction in total crude oil and PAHs reduction were observed at $5.0 \% \mathrm{NaCl}$ giving $12 \%$ and $8 \%$, respectively. Also, de Carvalho and de Fonseca (2005) observed that degradation of alcohol and hydrocarbons at different concentrations of $\mathrm{NaCl}$ ranged from $0.13 \%$ to $2.0 \%$ and found a better growth rate at $0.5 \%$. Thus, biodegradation of oil by microorganisms in the presence of high salinity was slow, this was because of high $\mathrm{NaCl}$ in medium might be disrupt cell membrane, denature some proteins, such as enzymes, or change the osmatic force, which any of these factors could be lethal for microorganisms (Kargi and Dincer, 2000 ; Minani- Tehrani et al., 2006).

\section{Effect of Incubation Periods}

The influence of incubation periods at 3,7 , 11 and 15 days on the growth of bacterial strains tested and their abilities to degrade $n$ hexadecane at $2.0 \%$ at different time intervals was studied using trypticase soy broth, at $\mathrm{pH}$ 7.0 and $30^{\circ} \mathrm{C}$ (Table 6).

The results demonstrated that as the time of incubation proceeded, there were an obvious increases in the bacterial growth (biomass) of the most bacterial strains. The highest bacterial biomass formation was observed at 11 days of incubation, this means that the tested bacterial strains had the abilities to utilize the tested substrate at this time. At 15 days of incubation, the end of the experiment, there was a progressive reduction in the bacterial biomass formation, these results were true with all the tested bacteria. This reduction could be attributed to the absence of assailable sources of carbon and energy in the food medium and/or to the presence of toxic metabolite compounds in the food medium. The obtained results are in the same line with those found by Mishra and Singh (2012), since they studied $n$-hexadecane degradation in mineral salt medium (MSM) as mediated by degrative enzymes using three bacteria identified as Pesudomonas aeruginosa, PSA5, Rhodococcus sp. NJ2 and Ochrobacterum intermedium $\mathrm{P} 2$ isolated from petroleum sludge. They reported also that $n$-hexadecane was degraded to $99 \%, 95 \%$ and $92 \%$ during 10 days of incubation, respectively. On the other hand, Yasin et al. (2014) found that, the percentage of crude oil consumption by Pesudomonas aeruginosa after 7 days of incubation was $70.7 \%$, while it was $71.5 \%, 74.1 \%$ and $78.11 \%$ for incubation period of 14,20 and 28 days, respectively. Also, Mahalingam and Sampath (2014) pointed that the better degradation of diesel oil was recorded by isolates of Pesudomonas spp. and Bacillus spp. with 1\% diesel oil at $37^{\circ} \mathrm{C}$ on the $7^{\text {th }}$ day.

\section{Biodegradation of Petroleum and Non- Petroleum Oils}

The registered bacterial growth (at $600 \mathrm{~nm}$ ) of the tested 10 bacterial strains as well as one bacterial Enterobacter clocace spp. disssolvens strain, used in this study as efficient bacteria in petroleum hydrocarbon degradation as affected by different carbon sources are shown in Table 7 .

As for the first group of carbon sources, crude oil, and their products, (diesel oil, engine oil and used engine oil), the tested bacteria had the ability to grow and utilize them as indicated by the values of their optical densities which were ranged as follows: $0.500-1.200,0.555-$ $1.216,0.604-1.321$ and $0.583-1.272$, respectively. In fact, it is well known that petroleum products are considered to be recalcitrant to microbial degradation and persist in ecosystems because of their hydrophobic nature and low avlability and they pose a significant threat to the environment (Abed et al., 2002; Sawadogo et al., 2014). Also, diesel oil and lubricants are hydrocarbon commonly used in Egypt and over the world. Soils and surface water contamination by these forms is common occurrence in most developing countries. 
Table 5. Bacterial growth $(O . D 600 \mathrm{~nm})$ of the tested 10 bacterial strains in trypticase soy broth supplemented with $\boldsymbol{n}$-hexadecane at $\mathbf{2 . 0} \%$ as affected by different salinity levels

\begin{tabular}{lcccc}
\hline \multicolumn{1}{c}{ Salinity level (\%) NaCl } & \multicolumn{4}{c}{ Bacterial growth (O.D 600 nm) } \\
\cline { 2 - 5 } Bacterial strain & $\mathbf{0 . 0 \%}$ & $\mathbf{0 . 5 \%}$ & $\mathbf{2 . 5 \%}$ & $\mathbf{5 . 0 \%}$ \\
\hline Bacillus licheniformis RdI -13 & 0.858 & 0.659 & 0.529 & 0.025 \\
Sphingobacterium thalpophilum QBII -6 & 1.480 & 1.355 & 1.197 & 0.482 \\
Pseudomonas nitroreducens RdI -14 & 1.380 & 1.060 & 0.845 & 0.465 \\
Bacillus subtilis ssp. subtilis GH -5 & 1.330 & 1.165 & 0.919 & 0.365 \\
Bacillus subtilis RdI -8 & 0.605 & 0.629 & 0.342 & 0.164 \\
Bacillus mojavensis QRII -7 & 1.236 & 1.011 & 0.538 & 0.277 \\
Bacillus atrophaeus GH -6 & 1.332 & 1.220 & 0.724 & 0.316 \\
Bacillus subtilis ssp. spizizenii RdI -3 & 0.980 & 0.742 & 0.672 & 0.053 \\
Bacillus licheniformis RdI -17 & 1.450 & 1.482 & 1.355 & 0.487 \\
Bacillus pumilus RdI -1 & 0.816 & 0.585 & 0.538 & 0.465 \\
LSD 0.05 & 0.0033 & 0.0033 & 0.0016 & 0.00116 \\
\hline
\end{tabular}

Table 6. Bacterial growth $(O . D 600 \mathrm{~nm})$ of the tested 10 bacterial strains in trypticase soy broth supplemented with $\boldsymbol{n}$-hexadecane as affected by different incubation periods

\begin{tabular}{lcccc}
\hline \multirow{2}{*}{ Incubation period } & \multicolumn{4}{c}{ Bacterial growth (O.D 600 nm ) } \\
\cline { 2 - 5 } Bacterial strain & $\mathbf{3}$ days & $\mathbf{7 ~ d a y s}$ & $\mathbf{1 1}$ days & $\mathbf{1 5}$ days \\
\hline Bacillus licheniformis RdI -13 & 0.563 & 0.580 & 1.052 & 0.838 \\
Sphingobacterium thalpophilum QBII -6 & 0.640 & 1.181 & 1.203 & 1.00 \\
Pseudomonas nitroreducens RdI- 14 & 0.662 & 1.095 & 1.377 & 1.211 \\
Bacillus subtilis ssp. subtilis GH -5 & 0.861 & 0.986 & 1.278 & 1.110 \\
Bacillus subtilis RdI- 8 & 0.095 & 0.561 & 0.769 & 0.6605 \\
Bacillus mojavensis QRII -7 & 0.201 & 0.657 & 1.077 & 0.948 \\
Bacillus atrophaeus GH- 6 & 0.600 & 0.741 & 1.228 & 1.000 \\
Bacillus subtilis ssp. spizizenii RdI -3 & 0.059 & 0.700 & 1.180 & 0.999 \\
Bacillus licheniformis RdI -17 & 0.905 & 1.128 & 1.277 & 1.156 \\
Bacillus pumilus RdI -1 & 0.340 & 0.611 & 1.062 & 0.893 \\
LSD 0.05 & 0.0033 & 0.0033 & 0.0033 & 0.0033 \\
\hline
\end{tabular}


This has been shown to have harmful effects on the environment and human being (Abioy et al., 2012).

Results presented in Table 7 show also, that only 5 bacterial strains, namely: Sphingobacterium thalpophilum QBII-6, Pseudomonas nitroreducens RdI-14, Bacillus subtilis ssp. subtilis GH-5, Bacillus atrophaeus GH-6 and Bacillus licheniformis RdI-17 as well as Enterobacter clocace spp. disssolvens strain showed the highest capacities to utilize these carbon sources used in this study. On the other hand, all the tested bacteria showed also considerable reduction in their growth rates on crude oil as carbon source in the growth medium. This could be considered a logic, since it is well known that petroleum contains numerous compounds of varying structural complexities. It is composed mainly of 95$99.5 \%$ hydrocarbons, as well as some bitumen and other materials. Hydrocarbons involved with alkanes, aromatic hydrocarbons, cyclic alkanes, fused ring compounds, and heterocyclics (Leahy and Colwell, 1990). Also, many microorganisms possess the capability to degrade petroleum, but in different degradation abilities for different components of petroleum (Li et al., 2002; Akbari and Ghoshal, 2014).

As to the presence of engine oil and used engine oil as a carbon source in the growth medium, it is clear from the previous results that all the tested organisms exhibited the ability to utilize them but in different degrees as indicated by the values of their optical densities at the end of the experiment. These values were lower with all tested organisms in the case of used engine oil. Recently, Sawadogo et al. (2014) studied the ability of two isolated strains of Acinetobacter (S2) and Pseudomonas (S7) to use the following hydrocarbons: Diesel, Total Quartz 9000 motor oil, SAE 40 used oil and gasoline as a sole carbon and energy source at a concentration of $3 \%(V / V)$. They found that no significant difference was recorded among hydrocarbons for strains $\mathrm{S} 2$ and $\mathrm{S} 7$ as well $(\mathrm{P}=0.235)$.

As for the second group of carbon sources, natural oils, the active 10 bacterial strains as well as Enterobacter clocace spp. disssolvens strains had the ability to utilize some vegetable oils namely corn oil and sunflower oil as well as their spent forms produced after cooking and repeated uses, and to find out its carbon source depletion could further oil consumption by the tested organisms.

The bacterial growth (at $600 \mathrm{~nm}$ ) of the tested organisms, used in this study as affected by the type of organic materials (corn oil- used corn oil-sunflower-used sunflower oil) as carbon source in Bushnell-Haas medium are shown in Table 7. Results showed that all the tested bacteria had the ability to metabolize and utilize all the tested fresh and used vegetable oils but in different degradations as indicated by the values of their optical densities owing to their growth. These values were ranging from 0.627 to 1.459 and from 0.551 to 1.400 in the case of corn oil, and used corn oil, respectively, and from 0.624 to 1.431 and from 0.584 to 1.205 in the case of sunflower, and used sunflower oils, respectively. Similar results on the efficient degradation of spent vegetable oils by the tested bacteria were ascertained. In line with that, Al-Darbi et al. (2005) studied the influence of nutrient and microbial environment on changes in bacterial numbers and exent and rates of degradation for various test oil (olive, mustard, canola and olive oils). They found that different oils respond in different ratios and extent to biodegradation depending on their stability, viscosity and composition. Also, in the same year Malatova (2005) studied the ability of seven bacterial strains to utilize larger and more complex structures of hydrocarbons, and other organic compounds (olive oil- peanut oil- corn oilcanola oil), and the author pointed out that the highest bacterial growth on olive oil and canola oil was elucidated by their composition, with high percentage of monounsaturated fatty acid $(62-72 \%)$ and lower percentage of polyunsaturated (9-32\%) make them an easy target for microbial utilization. Recently, Mahalingam and Sampath (2014) used different carbon sources such as diesel oil, corn oil and sunflower oil to study the bacterial growth of three efficient diesel oil degrading bacteria. The higher percentage of microbial biomass was recorded in BushnellHaas medium supplemented with sunflower oil as a carbon source at $1 \%$ in the presence of ammonium sulfate as a nitrogen source.

Again the only 5 bacterial strains namely: Sphingobacterium thalpophilum QBII-6, Pseudomonas nitroreducens RdI-14, Bacillus subtilis ssp subtilis GH-5, Bacillus atrophaeus 
Table 7. Growth and ability of the tested bacteria, to use different petroleum hydrocarbon and natural oils as carbon source as grown in Bushnell-Haas broth for 11 days of incubation

\begin{tabular}{|c|c|c|c|c|c|c|c|c|}
\hline \multirow{3}{*}{$\begin{array}{l}\text { Organic compound } \\
\text { Bacterial strain }\end{array}$} & \multicolumn{8}{|c|}{ Bacterial growth $(0 . D 600 \mathrm{~nm})$} \\
\hline & \multicolumn{4}{|c|}{ Petroleum oils } & \multicolumn{4}{|c|}{ Non-petroleum oils } \\
\hline & $\begin{array}{c}\text { Diesel } \\
\text { oil }\end{array}$ & $\begin{array}{c}\text { Used } \\
\text { engine } \\
\text { oil }\end{array}$ & $\begin{array}{c}\text { Engine } \\
\text { oil }\end{array}$ & $\begin{array}{c}\text { Crude } \\
\text { oil }\end{array}$ & $\begin{array}{c}\text { Corn } \\
\text { oil }\end{array}$ & $\begin{array}{c}\text { Used } \\
\text { corn } \\
\text { oil }\end{array}$ & $\begin{array}{c}\text { Sunflower } \\
\text { oil }\end{array}$ & $\begin{array}{c}\text { Used } \\
\text { sunflower } \\
\text { oil }\end{array}$ \\
\hline Bacillus licheniformis RdI -13 & 0.666 & 0.684 & 1.00 & 0.500 & 1.051 & 1.00 & 1.051 & 1.001 \\
\hline Sphingobacterium thalpophilum QBI -6 & 1.1065 & 1.133 & 1.156 & 1.055 & 1.444 & 1.333 & 1.344 & 1.139 \\
\hline Pseudomonas nitroreducens RdI 14 & 1.159 & 1.183 & 1.200 & 1.060 & 1.456 & 1.367 & 1.431 & 1.191 \\
\hline Bacillus subtilis ssp. subtilis GH- 5 & 1.1665 & 1.250 & 1.311 & 1.050 & 1.450 & 1.343 & 1.394 & 1.078 \\
\hline Bacillus subtilis RdI -8 & 0.555 & 0.606 & 0.650 & 0.500 & 0.777 & 0.655 & 0.774 & 0.584 \\
\hline Bacillus mojavensis QRII -7 & 0.599 & 0.583 & 0.615 & 0.583 & 0.700 & 0.555 & 0.806 & 0.606 \\
\hline Bacillus atrophaeus GH- 6 & 1.216 & 1.260 & 1.311 & 1.100 & 1.459 & 1.400 & 1.429 & 1.079 \\
\hline Bacillus subtilis ssp. spizizenii RdI- 3 & 0.630 & 0.646 & 0.649 & 0.610 & 0.677 & 0.616 & 0.685 & 0.585 \\
\hline Bacillus licheniformis RdI -17 & 1.255 & 1.322 & 1.383 & 1.200 & 1.479 & 1.433 & 1.494 & 1.139 \\
\hline Bacillus pumilus RdI- 1 & 0.580 & 0.601 & 0.604 & 0.565 & 0.627 & 0.551 & 0.624 & 0.611 \\
\hline Enterobacter clocace spp. disssolvens & 1.205 & 1.272 & 1.321 & 1.200 & 1.416 & 1.315 & 1.415 & 1.205 \\
\hline LSD 0.05 & 0.0097 & 0.0097 & 0.0097 & 0.0097 & $0.0096 c$ & 0.0097 & 0.0092 & 0.0097 \\
\hline
\end{tabular}

GH-6 and Bacillus licheniformis RdI-17 as well as Enterobacter cloacae strain showed the highest capability to metabolize and utilize these vegetables oils in fresh and spent forms. On the basis of these results, it could be concluded that these five bacterial strains as well as Enterobacter cloacae strain have high ability to utilize a diverse range of organic compounds, vegetable oil, and petroleum hydrocarbon products.

Finally, in order to increase the feasibility of these bacteria as the potential commercial strains, future studies need to clarify the factors affecting the capability and efficiency of hydrocarbons and crude oil degradation such as nutrients, oxygen content and physical state of oil in the field under realistic conditions.

\section{REFERENCES}

Abed, M.M.R., N.M.D. Safi, J. Koster, D. deBeer, Y. El-Nahhal, J. Rullkotter and F. Garci-Pichel (2002). Microbial diversity of a heavily polluted microbial mat and its community changes following degradation of petroleum compounds. Appl. Environ. Microbiol., 68 (4):1674- 1683.

Abioy, O.P., P. Agamuthu and A.R. Abdul Aziz (2012). Biodegradation of used motor oil in soil using organic waste amendments. Biotechnol. Res. Int., Article ID., 587041, 8.

Akbari, A. and S. Ghoshal (2014). Pilot-scale bioremediation of a petroleum hydrocarboncontaminated clayey soil from a sub-arctic site, J. Hazard. Mat., 280: 595-602.

AL-Darbi, M.M., N.O. Saeed, M.R. Islam and K. Lee (2005). Biodegradation of natural oils in seawater. J. Energy Sources, 27(1-2):

Balba, M.T., N. Al-Awadhi and R. Al-Daher (1998). Bioremediation of oil-contaminated soil: Microbiological methods for feasibility assessment and field evaluation. J. Microbiol. Meth., 32: 155-164.

Benedek, T., I. Máthé, A. Táncsics, S. Lányi and K. Márialigeti (2010). Investigation of hydrocarbon-degrading microbial communities of petroleum hydrocarbon contaminated soils in Harghita county, Romania. Geologie şi Ingineria Mediului, vol. XXIV, Nr. 2. 
Bento, F.M., F.A. Camargo, B. Okeke and W. T. Fankenberger (2003). Bioremediation of soil contaminated by diesel oil. Braz. J. Microbiol., 34: 65-68.

Bidoia, E.D., R.N. Montagnolli and P.R.M. Lopes (2010). Microbial biodegradation potential of hydrocarbons evaluated by colorimetric technique: A case study, In: Current Res., Technol. and Ed. Topics in Appl. Microbiol. and Microbial Biotechnol., Mendez-Vilas A. (Ed.), FORMATEX, Badajoz, Spain.

Bille, E.B., D.J. Leto, M.E. Bougnoux, J.L. Beretti, A. Lotz, S. Suarez, J. Meyer, O. JoinLambert, P. Descamps, N. Grall, F. Mory, L. Dubreuil, P. Berche, X. Nassif and A. Ferroni (2012). MALDI-TOF MS Andromas strategy for the routine identification of bacteria, mycobacteria, yeasts, Aspergillus spp. and positive blood cultures Clin. Microbiol. Infect., 18: 1117-1125.

Biswas, S. and J.M. Rolain (2013). Use of MALDI-TOF mass spectrometry for identification of bacteria that are difficult to culture. J. Microbiol. Meth., 92: 14- 24.

Bizzini, A., C.J. Durussel, B., G. Greub and G. Prod'hom. (2010). Performance of matrixassisted laser desorption ionization-time of flight mass spectrometry for identification of bacterial strains routinely isolated in a clinical microbiology laboratory. J. Clin. Microbiol., 48:1549-1554.

Bossert, I. and R. Bartha (1984). The Fate of Petroleum in Soil Ecosystems. In: Petroleum Microbiology, RM Atlas (Ed.), Macmillan, New York, 453-473.

Cappello, S., R. Denaro, M. Genovese, L. Giuliano and M.M. Yakimov (2007). Predominant growth of Alcanivorax during experiments on "oil spill bioremediation" in mesocosms. Microbiol. Res., 162 (2): 185-190.

Chu, W. and C.Y. Kwan (2003). Remediation of contaminated soil by a solvent/surfactant system. Chemosphere, 53: 9-15.

Costes, J.M. and V. Druelle (1997). Polyciclic aromatic hydrocarbons in the environment: The rehabilitation of old industrial sites. Oil and Gas Sci. and Technol., 52: 425-440.
Das, N. and P. Chandran (2011). Microbial degradation of petroleum hydrocarbon contaminants: An overview. Biotechnol. Res. Int., vol. 2011, Article ID 941810, 13 pages, 2011. doi:10.4061/2011/941810.

de Carvalho, C. and M.M.R. de Fonseca (2005). Degradation of hydrocarbons and alcohols at different temperatures and salinities by Rhodococcus erythropolis DCL14. FEMS Microbiol. Ecol., 51:389-399.

Dindar, E., F.O.T. Şağban and H.S. Başkaya (2013). Bioremediation of petroleumcontaminated soil. J. Biol. Environ. Sci., 7 (19): 39-47.

El-Naas, M.H., J.A. Acio and A.E. El-Telib (2014). Aerobic biodegradation of BTEX: Progresses and prospects. J. Environ. Chem. Engin., 2: 1104-1122.

Haasanshahian M., G. Emtiazi and S. Cappello (2012). Isolation and characterization of crude-oil-degrading bacteria from the Persian Gulf and the Caspian Sea. Marine Pollution Bulletin, 64: 7-12.

Hanson, K.G., J.D. Desai and AJ. Desai (1993). A rapid and simple screening technique for potential crude oil degrading microorganisms. Biotechnol. Tech., 7(10): 745-748.

Isermeyer, H. (1952). Eine Einfache Methode sur Bestimmung der Bodenatmung und der Karbonate im Boden. Z. Pflanzanernah Bodenk, 56:26-38.

Kargi, F. and A.R. Dinçer (2000). Use of halophilic bacteria in biological treatment of saline wastewater by fed-batch operation, Wat. Environ. Res., 72(2): 170-174.

Koshlaf, E. and A.S. Ball (2017). Soil bioremediation approaches for petroleum hydrocarbon polluted environments. AIMS Microbiol., 3 (1): 25-49.

Krasny, L., R. Hyneka and I. Hochela (2013). Identification of bacteria using mass spectrometry techniques. Int. J. Mass Spectrometry, 353: 67-79.

Kwapisz, E., J. Wszelaka, O. Marchut and S. Bielecki (2008). The effect of nitrate and ammonium ions on kinetics of diesel oil degradation by Gordonia alkanivorans S7. Int. Biodeterior. Biodegrad., 61: 214-222. 
Leahy, J.G. and R.R. Colwell (1990). Microbial degradation of hydrocarbons in the environment. Microbiol. Rev., 54: 305 -315.

Li, P., T. Sun, F. Stagnitti, C. Zhang, H. Zhang, $\mathrm{X}$. Xiong, G. Allinson, X. Ma and M. Allinson (2002). Field-scale bioremediation of soil contaminated with crude oil, Environ. Eng. Sci., 19: 277-289.

Mahalingam, P.U. and N. Sampath (2014). Optimization of growth condition for diesel oil degrading bacterial strains. Adv. Appl. Sci. Res., 5 (6):91-96.

Malatova, K. (2005). Isolation and characterization of hydrocarbon degrading bacteria from environmental habitats in western new York State. M.Sc. Sci. in Chem. Thesis, Chem. Dept., Rochester Inst. Technol., Rochester, 108.

Mandri, T. and J. Lin (2007). Isolation and characterization of engine oil degrading indigenous microorganisms in KwazuluNatal, South Afr. T. Afri. J. Biotech., 6 (1): 23-27.

Margesin, R. and F. Schinner (2001). Biodegradation and bioremediation of hydrocarbons in extreme environments. Appl. Microbiol. Biotechnol., 56(5-6): 650663.

Mariano, A.P., A.P.D.A.G. Kataoka, D.D.F.D. Angelis and D.M. Bonotto (2007). Laboratory study on the bioremediation of diesel oil contaminated soil from a petrol station. Braz. J. Microbiol., 38: 346-353.

Mariano, A.P., R.C. Tomasella, C.D. Martino, R.M.A. Filho, M.H. Regali, J. Seleghim and D.D.F.D. Contiero (2009). Aerobic biodegradation of butanol and gasoline blends. Biomass and Bioenergy, 33 : 11751181.

Meredith, W., S.J. Kelland and D.M. Jones (2000). Influence of biodegradation on crude oil acidity and carboxylic acid composition, Org. Geochem., 31: 1059- 1073.

Minani-Tehrani, D., A. Herfatmanesh, F. AzariDehkordi and S. Minooi (2006). Effect of salinity on biodegradation of aliphatic fraction of crude oil in soil. Pak. J. Bio. Sci., 9 (8): 1531-1535.
Mishra, S. and S.N. Singh (2012). Microbial degradation of $n$-hexadecane in mineral salt medium as mediated by degradative enzymes. Bioresource Technol., 111: 148154.

Mittal, A. and P. Singh (2009). Isolation of hydrocarbon degrading bacteria from soil contaminated with crude oil spills. Indian J. Exp. Biol., 47: 760-765.

Mrozik, A. and Z. Piotrowska-Seget (2010). Biougmentation as a strategy for cleaning up of soils contaminated with aromatic compounds, Microbiol. Res., 165 (5): $363-$ 375 .

Okoh, A.I. (2006). Biodegradation alternative in the cleanup of petroleum hydrocarbon pollutants. Biotechnol. and Molec. Biol. Rev., 1(2): 38-50.

Perfumo, A., I. M. Banat, R. Marchant and L. Vezzulli (2007). Thermally enhanced approaches for bioremediation of hydrocarboncontaminated soils. Chem., 66 (1): 179-184.

Pirôllo, M.P., A.P. Mariano, R.B. Lovaglio, S.G. Costa, V. Walter, R. Hausmann and J. Contiero (2008). Biosurfactant synthesis by Pseudomonas aeruginosa LBI isolated from a hydrocarbon- contaminated site. J. Appl. Microbiol., 105: 1484-1490.

Qin, X., J.C. Tang, D.S. Li and Q.M. Zhang (2012). Effect of salinity on the bioremediation of petroleum hydrocarbons in a salinealkaline soil. Lett. Appl. Microbiol., 55: 210217

Rahman, K.S.M., J. Thahira-Rahman and P. Lakshmanaperumalsamy (2002). Towards efficient crude oil degradation by a mixed bacterial consortium I.M. Banat, Bioresource Technol., 85:257-261.

Rahman, K.S.M., N. Vasudevan, P. Lakshmanaperumalsamy (1999). Enhancement of biosurfactant production to emulsify different hydrocarbons. J. Environ. Pollut., 6: $87-93$.

Sabate, J., M. Vinas and A.M. Solanas (2004). Laboratory-scale bioremediation experiments on hydrocarbon-contaminates soils. Int. Biodet. Biodeg., 52: 19-25. 
Salmon, C., J.L. Crabos, J.P. Sambuco, J.M. Bessiere, A. Basseres, P. Caumette and J.C. Baccou (1998). Artificial wetland performances in the purification efficiency of hydrocarbon wastewater, Water Air Soil Pollut., 104: 313 - 329.

Sathishkumar, M., A. Binupriya, S. Baik and S. Yun (2008). Biodegradation of crude oil by individual bacterial strains and a mixed bacterial consortium isolated from hydrocarbon contaminated areas. Clean., 36: 92-96.

Sauer, S. and M. Kliem (2010). Mass spectrometry tools for the classification and identification of bacteria. Nat. Rev. Microbiol., 8:74-82.

Sawadogo, A., C.O.C. Harmonie, J.B. Sawadogo, A. Kaboré, A.S. Traoré1 and D. Dianou (2014). Isolation and characterization of hydrocarbon-degrading bacteria from wastewaters in Ouagadougou, Burkina Faso. J. Environ. Prot., 5: 1183-1196.

Sonawdekar, S. (2012). Bioremediation a boon to hydrocarbon Degradation, Int. J. Environ. Sci., 2 (4): 2408-2424.

Ueno, A., Y. Ito, I. Yumoto and H. Okuyama (2007). Isolation and characterization of bacteria from soil contaminated with diesel oil and the possible use of these in autochthonous bioaugmentation. World J. Microbiol. Biotechnol., 23: 1739-1745.

Van Hamme, J.D., J.A. Odumeru and O.P. Ward (2000). Community dynamics of a mixed bacterial culture growing on petroleum hydrocarbons in batch culture. Cana. J. Microbiol., 46: 441-450.

Walworth, J., J. Braddock and C. Woolard (2001). Nutrient and temperature interactions in bioremediation of Cryic soil. Cold Reg. Sci. and Technol., 32: 85-91.

Wang, Y.R., Q. Chen, C.S. Hui and L.F. Qin (2013). Characterization of Staphylococcus aureus isolated from clinical specimens by Matrix Assisted Laser Desorption/Ionization Time-off light Mass Spectrometry. Biomed. Environ. Sci., 26(6): 430-436.

Williams, S.D., D.E. Ladd and J.J. Farmer (2006). Fate and Transport Of Petroleum Hydrocarbons In Soil And Ground Water At Big South Fork National River and Recreation Area, Tennessee And Kentucky" - U S Geological Survey, 2002-2003, 7-10.

Yasin, A.R., S.A. Salman and I.K. Al-Mayaly (2014). Bioremediation of polluted water with crude oil in South Baghdad Power Plant. Iraqi J. Sci., 55 (1):113-122. 


\title{
إمكانية التحلل الحيوى الميكروبى لزيوت البترول والزيوت الطبيعية بواسطة البكتريا الطبيعية المحللة للهيدروكربون والمغزولة من مواقع ملوثئة بالبترول
}

\author{
محمد عبدالمنعم فهمى - سمير حماد سالم - حسن إبراهيم عبدالفتاح - بحيرى حميا عقل \\ قسم الميكروبيولوجيا الزر اعية ـ كلية الزر اعة - جامعة الزقازيق ـ مصر
}

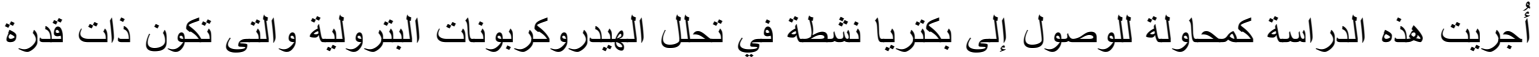

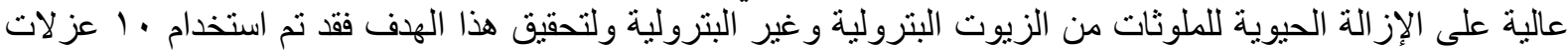

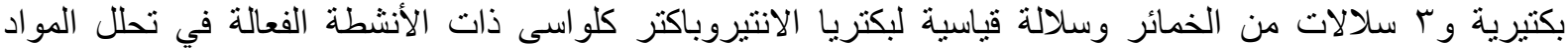

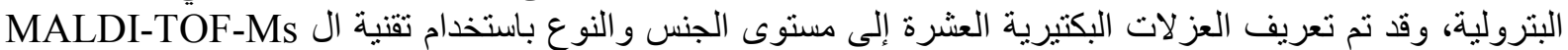

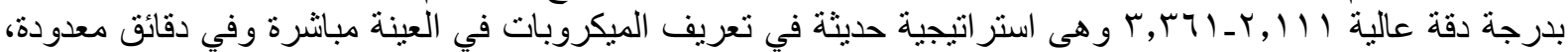
وقد تم استخدام اثثين من التقنيات هما طريقة قياس التنفس (قياس CO

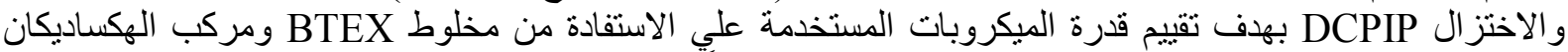

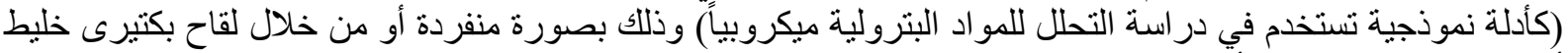

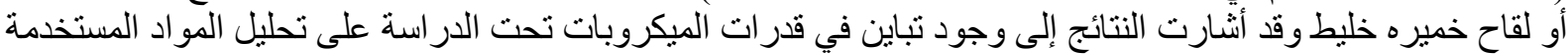

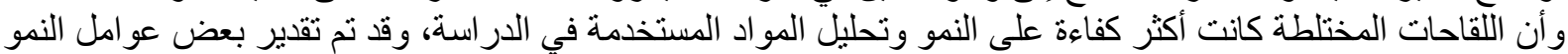

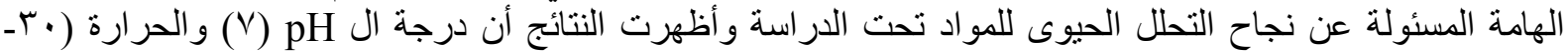

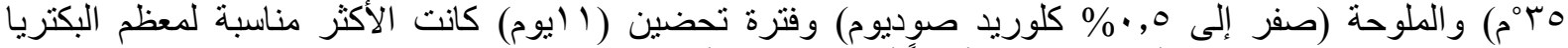

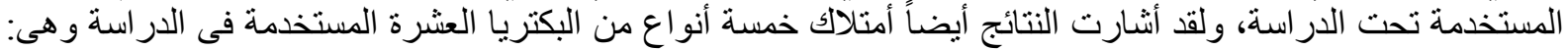
Sphingobacterium thalpophilum QBII-6, Pseudomonas nitroreducens RdI-14, Bacillus subtilis ssp subtilis GH-5, B. atrophaeus GH-6 and B. licheniformis RdI-17 as well as Ent. clocace spp.

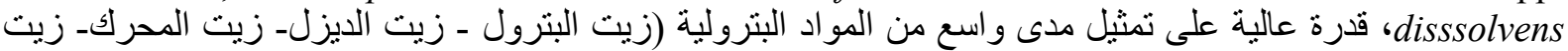

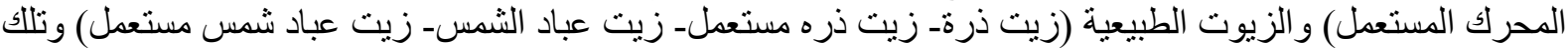

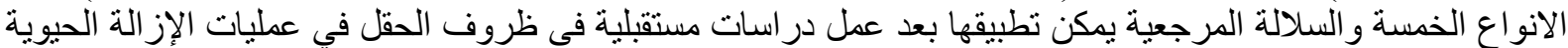

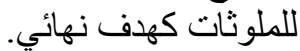

أستاذ الميكروبيولوجي - كلية الزر اعة - جامعة عين شمس. أستاذ الميكروبيولوجي المتفرغ - كلية الزر اعة - جامعة الزقازيقة عالئ. 